\title{
APLIKASI PUPUK ORGANIK CAIR DAN BIOPESTISIDA PADA PERTANIAN PADI ORGANIK DI SUBAK REJASA KECAMATAN PENEBEL KABUPATEN TABANAN
}

\author{
N.N. Soniari ${ }^{1}$, N.M. Witariadi ${ }^{2}$, dan N.K. Karyati ${ }^{3}$
}

\begin{abstract}
ABSTRAK
Salah satu tujuan pendampingan teknologi di daerah Jegu dan Rejasa kecamatan Penebel, Kabupaten Tabanan ini adalah untuk peningkatan produktivitas padi yang sehat dengan penerapan pupuk organik cair dan biopestisida buatan petani sendiri,. Metode yang ditempuh untuk mencapai tujuan tersebut adalah melalui pendidikan, pelatihan, simulasi sains dan teknologi, pendampingan, dan disain teknologi tepat guna. Semua kegiatan tersebut diwujudkan dalam bentuk sekolah lapang yang dihadiri oleh 25 anggota Subak Rejasa dengan membuat demonstrasi plot padi sehat seluas 25 hektar. POC (Pupuk Organik Cair) yang terbuat dari kotoran hewan, tebu, Gamal, umbi ubi jalar dan bahan lokal lainnya, diaplikasikan pada dosis $450 \mathrm{ml} / 25 \mathrm{~L}$ air setiap minggu, dan biopestisida berbahan umbi gadung dan urin sapi terfermentasi. Pupuk organik cair dan biopestisida yang dibuat oleh anggota Subak Rejasa telah dilakukan analisis laboratorium dengan hasil sebagai berikut: kandungan C-org (1,540\%): N (0,160\%); P (85,120 ppm); K (95,400 ppm); pH $(7,78)$ dan DHL $(32,200 \mathrm{mS})$. Aplikasi Biopestisida dan POC pada demplot pertanian padi organik, pada vaieta sinpari30 memperlihatkan pertumbuhan vegetatif seperti jumlahan akan (20 -24), batang kuat dan warna daun hijau sehat dan generatif ( jumlah bulir permalai 185 - 255 dan hasil gabah $(5,8$ ton/ha ). Pengolahan limbah ternak menjadi POC dan biopestisa dan memberikan sumber penghasilan tambahan baru bagi petani disamping efisiensi ekonomi dalam penggunaan pupuk dan kembalinya keragaman hayati secara perlahan.
\end{abstract}

Kata Kunci: pupuk organik cair, biopestisida, subak rejasa.

\begin{abstract}
One of the goals of science and technology for the Region of Jegu and RejasaVilages in Penebel District, Tabanan Regency is a healthy increase rice productivity by application of liquid organic fertilizer and artificial biopesticides farmers themselves. The method adopted to achieve these goals is through education, training, simulation science and technology, mentoring, and design appropriate technology applied.All such activities are realized in the form of a field school that was attended by 25 members of SubakRejasa by making healthy rice demonstration plot 25 acres.POC and biopesticide made from animal waste, sugar cane, Gamal, yam tubers and other local materials, applied at a dose of $450 \mathrm{ml} / 25 \mathrm{~L}$ of water every week. Liquid organic fertilizer and biopesticide made by members of SubakRejasa have done laboratory analysis with the following results: the content of C-org (1,540\%): N (0.160\%); P (85.120 ppm); K (95.400 ppm); pH (7.78) and DHL (32,200 $\mathrm{mS})$. The results of the application of POC and biopesticideson the rice varieties "Inpari 30", quite good, vegetative growth performance lush, green leaves, stronger stems no pests and diseases,number of tillers $20-24$, and the generative phase, pithy grain, grain number between 185-255/stalk and grain yield at harvest 5.8 tonnes / ha. The processing of livestock wastes into POC and biopesticides
\end{abstract}

${ }^{1}$ Staf Pengajar Fakultas Pertanian Universitas Udayana, nengahsoniari@ymail.com

${ }^{2}$ Staf Pengajar Fakultas Peternakan Universitas Udayana, witarimade@yahoo.com

${ }^{3}$ Staf Pengajar Universitas Dwijendra 
provides a new source of additional income for farmers in addition to economic efficiency in the use of fertilizers and the slow return of biodiversity.

Keywords: liquid organic fertilizer, biopesticides, subak rejasa.

\section{PENDAHULUAN}

Desa Rejasa merupakan daerah Pertanian dengan Mayoritas Penduduk sebagai Petani .Selain itu Daerah ini juga menghasilkan Komoditi Perkebunan seperti kelapa, kakau, dan Sayur-sayuran,dan lain lain yang saat ini Masyarakat Desa Rejasa sudah membentuk Kelompok-kelompok tani ada Kelompok Ternak, kelompok Ikan dan lain - lain . Tetapi yang paling menonjol di bidang pertanian di Desa Rejasa adalah di bidang tanah basah,bahkan pernah mencapai juara I tingkat Nasional tahun 1980.

Komoditas unggulan dari subsektor pertanian tanaman pangan adalah padi, palawija, ubi jalar dan sayur-sayuran.Produksi padi lokal kawasan ini mencapai 1.891 ton pada tahun 2012.Persoalan yang dijumpai terkait dengan sector pertanian tanaman pangan diantaranya padi sebagai komoditas unggulan wilayah belum memberikan pendapatan yang memadai bagi petani.Untuk meningkatkan pendapatan petani, pemerintah Kabupaten Tabanan mengembangkan program beras sehat, yaitu beras yang diproduksi dengan menerapkan pertanian atau memanfaatkan input kimia yang sangat minim dan lebih mengarah ke pertanian organik..Pengembangan beras sehat, selain dapat menekan penggunaan pupuk kimia yang harganya relative mahal juga memberikan harga produk yang lebih tinggi rata-rata sebesar Rp. 3.000 rupiah per kg.Akan tetapi, teknologi untuk memproduksi beras sehat belum dikuasai petani sehingga perlu dilakukan pendampingan dalam rangka alih teknologi pertanian tersebut.Di Desa Rejasa terdapat subak (kelompok tani) dengan luas lahan 25 ha telah siap untuk mengaplikasikan teknologi tersebut. Dengan menjadikan subak tersebut sebagai pilot proyek diharapkan akan dapat merangasang subak lainnya mengaplikasikan pertanian beras sehat tersebut. Pemanfaatan limbah kotoran ternak untuk menunjang pertanian padi sehat merupakan hal penting yang harus diberikan sentuhan teknologi fermentasi dalam menghasilkan pupuk organik cair dan biopestisida.

\section{METODE PELAKSANAAN}

Pemberdayaan masyarakat/ pengembangan SDM melalui pendidikan, pelatihan dan pendampingan. Pemerintah daerah Tabanan menyelenggarakan sekolah lapang yang melibatkan Penyuluh, Pekaseh, dan seluruh anggota subak Rejasa sebagai peserta. Tim IbW masuk melakukan pendampingan dalam sekolah lapang ini.,yaitudengan mengadakan pertemuan secara berkala dan berkelanjutan antara pendamping dengan masyarakat sasaran hingga ipteks yang dialihkan dapat dilaksanakan secara mandiri oleh masyarakat. Petani sebagai anggota subak mendapatkan pendidikan khususnya bidang pertanian organik, dari proses pembuatan pupuk organic cair dan biopestisida serta aplikasinya, pengelolaan tanah, budidaya padi sehat hingga panen. Aksi lain adalah studi banding dan pelatihan ke tempat pembuatan pupuk organik yang sudah eksis berproduksi di Kabupaten Tabanan.

\section{Tahap kegiatan}

Pelaksananan kegiatan pembuatan pupuk organik cair dan biopestisida untuk menunjang pertanian padi sehat adalah sebagai berikut :

(1) Partisipasi aktif tim dalam setiap jadwal sekolah lapang

VOLUME 17 NOMOR 1, JANUARI 2018 | 66 
(2) Penyuluhan tentang pentingnya pertanian organik dan aplikasi teknologi fermentasi untuk pengolahan pupuk organic cair dan biopestisida

(3) Studi banding dan pelatihan

(4) Pembuatan laboratorium mini untuk produksi POC dan Biopestisida

(5) Aplikasi POC dan biopestisida pada demplot seluas 25 are, disertai pendampingan dan bimbingan teknis secara berkala dari tim IbW dan penyuluh

\section{HASIL DAN PEMBAHASAN}

Pertemuan untuk pembahasan SOP dan demplot pertanian padi sehat dilakukan bersamaan dengan pelaksanaan sekolah lapang yang bertempat di "Koperasi Kuat"desa Rejasa, pada tanggal 11 Juli 2016.(Foto terlampir).Petani yang terlibat adalah petani dari subak Rejasa, jumlahnya 25 orang. Anggota subak ini rutin mengikuti sekolah lapang setiap tanggal 15, dilaksanakan oleh Bappeda yang dipimpin Bappeluh dan tim kami sebagai pendamping. Sekolah lapang ini bertujuan untuk menangkap permasalahan yang dihadapi petani, selanjutnya memberikan petunjuk/pedoman dan solusi untuk meningkatkan potensi serta kaji terap Ipteks terhadap pencanangan program beras sehat.Kesuksesan program ini tentu saja didukung oleh adanya penerapan SOP yang benar tentang pertanian padi sehat, ramah lingkungan menuju pertanian organik. Luas lahan yang dijadikan demplot seluas 25 are, dari 25 ha sawah yang dikerjakan oleh petani anggota subak Rejasa.

Pertanian padi sehat memerlukan perlakuan khusus dalam pengelolaannya seperti pemberian pupuk organik untuk pertumbuhannya, tidak menggunakan pestisida kimia melainkan biopestisida dalam pengendalian hama dan penyakitnya, sehingga tidak mencemari lingkungan tanah, air maupun produk berupa beras yang akan dikonsumsi. Hal penting lainnya adalah mengembalikan keseimbangan alam dan keragaman hayati setempat. Berkaitan dengan permasalahan itu maka diperlukan lab mini atau rumah instalasi untuk pembuatan pupuk organik cair (POC) dan biopestisida. Pada saat setelah usai sekolah lapang, tim, Bappeluh dan semua peserta meninjau lokasi bakal rumah instalasi, rumah ini harus ada kandang sapinya, saluran urine, penampungan dan tangga aerator tempat pemrosesan urine serta tangki fermentasi.

Partisipasi aktif dan antusiasme anggota subak sangat baik, hal ini ditunjukkan oleh kehadiran peserta (100\%), diskusi yang hidup dalam setiap pertemuan maupun pelatihan (Tabel 1).

Tabel 1. Partisipasi Anggota Subak dalam Kegiatan IbW

\begin{tabular}{|r|l|c|c|}
\hline \multirow{2}{*}{ No } & \multicolumn{1}{|c|}{ Kegiatan } & \multicolumn{2}{c|}{ Anggota subak } \\
\cline { 3 - 4 } & & & Jumlah \\
\hline A & Kegiatan Penyuluhan - Pelatihan Singkat & & \% \\
\hline 1 & Absensi/Kehadiran & 25 & 56 \\
\hline 2 & Mengungkapkan masalah & 14 & 80 \\
\hline 3 & Ikut mempraktekkan & 20 & \\
\hline & & & 100 \\
\hline B & Kegiatan Demplot & & 100 \\
\hline 1 & Mengelola Lab Mini & 25 & 48 \\
\hline 2 & Demplot padi organik (bergilir) & 25 & \\
\hline 3. & Aplikasi POC \& biopestisida (mandiri) & 12 & \\
\hline
\end{tabular}

Kegiatan berikutnya tanggal 16 Juli 2016, yaitu studi banding ke Desa Klating tepatnya di Simantri 027.Semua peserta sekolah lapang diikutkan meninjau lokasi pembuatan POC dan biopestisida. Simantri 027 ini sudah memproduksi pupuk organic dan biopestisida untuk memenuhi kebutuhan petani di sebagian besar kabupaten Tabanan, dan melayani pesanan kabupaten lain di Bali. Peserta diberikan kursus singkat, mulai dari model pembuatan kandang sapi, pembuatan instalasi yang benar sehingga menghasilkan POC dan biopestisida berkualitas, pelatihan membuat POC dan

\section{7 | BULETIN UDAYANA MENGABDI}


biopestisida dengan dekomposer hasil pembiakan di Simantri 027 yang diberikan oleh praktisi berpengalaman .

Pembuatan Lab Mini (rumah instalasi) POC dan Biopestisida dilaksanakan Senin tanggal 25 Juni 2 Agustus 2016 , pada tempat yang sudah disepakati oleh anggota subak. Team menyerahkan seperangkat alat instalasi Biopestisida sehingga dapat segera beroperasi.Komposisi bahan untuk POC terdiri dari : Urin sapi, biofermentor, molasses, batang tebu dan gamal. Urin sapi dan biofermentor sebagai sumber mikroorganisme, molasses dan batang tebu sebagai sumber energy, gamal sumber karbohidrat. Sedangkan untuk biopestisida berbahan : uirn sapi, biakan Trichoderma, molasses, umbi gadung yang difermentasi 10 hingga 21 hari. Trichoderma.merupakan agens hayati yang bersifat antagonis yang mampu menekan pertumbuhan jamur-jamur pathogen /penyebab penyakit tanaman, serta mampu mempercepat proses pelapukan bahan organik,.Umbi gadung merupakan sumber karbohidrat bagi kelangsungan hidup Trichoderma.

Hasil produksi POC dianalisis di Laboratorium Tanah dan Lingkungan, sehingga kualitas serta komposisinya dapat diketahui. Ternyata kualitasnya cukup baik : C-org $(1,540 \%)$ : N(0,160\%) ; $\mathrm{P}(85,120 \mathrm{ppm}) ; \mathrm{K}(95,400 \mathrm{ppm}) ; \mathrm{pH}(7,78)$ dan DHL $(32,200 \mathrm{mS})$. Aplikasi Biopestisida dan POC pada demplot pertanian padi organik, pada vaietas inpari 30 memperlihatkan pertumbuhan vegetatif seperti jumlah anakan (20 -24), batang kuat dan warna daun hijau sehat dan generatif (jumlah bulir permalai 185 - 255dan hasil gabah (5,8 ton/ha).

Petani anggota subak Rejasa telah berhasil mengadopsi teknologi fermentasi POC dan biopestisida dengan baik, dan mengaplikasikan pada demplot kelompok serta pada lahan masing-masing secara mandiri.Pengolahan limbah ternak menjadi POC dan biopestisida memberikan sumber penghasilan tambahan baru bagi petani disamping efisiensi ekonomi dalam penggunaan pupuk. Aplikasi pupuk organic dan biopestisida secara perlahan namun pasti akan mengurangi pencemaran oleh limbah, mengembalikan keragaman hayati dan memperbaiki kualitas kesehatan lingkungan.

Kegiatan IbW terkait Aplikasi POC dan Biopestisida pada Demplot padi organik dapat dilihat pada Gambar 1.

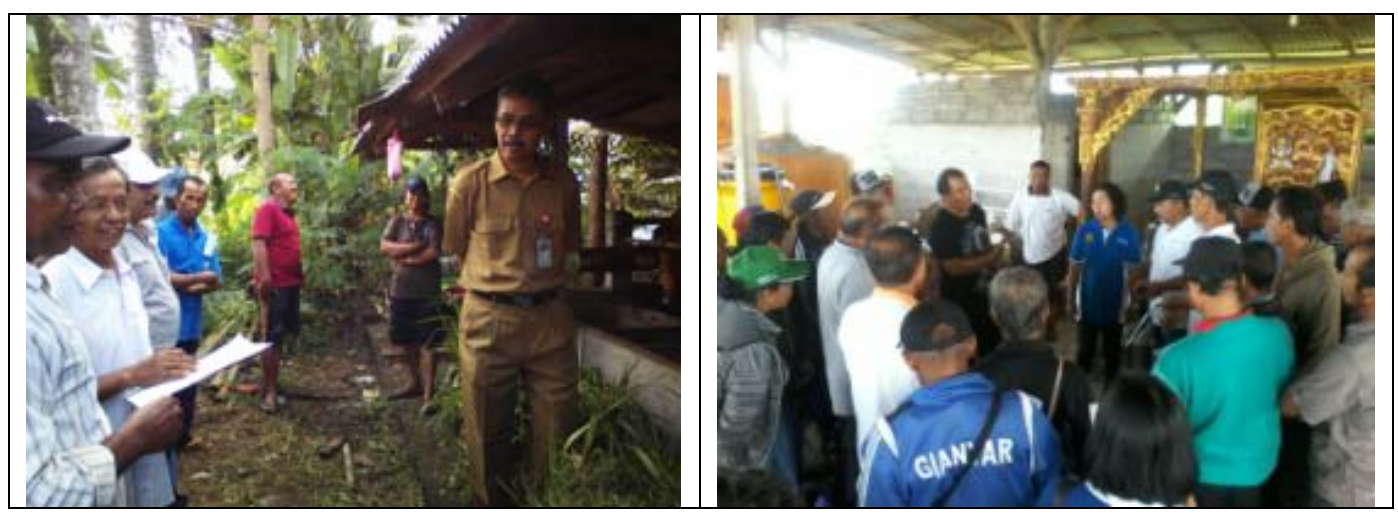


Aplikasi Pupuk Organik Cair Dan Biopestisida Pada Pertanian Padi Organik Di Subak Rejasa, Kecamatan Penebel, Kabupaten Tabanan

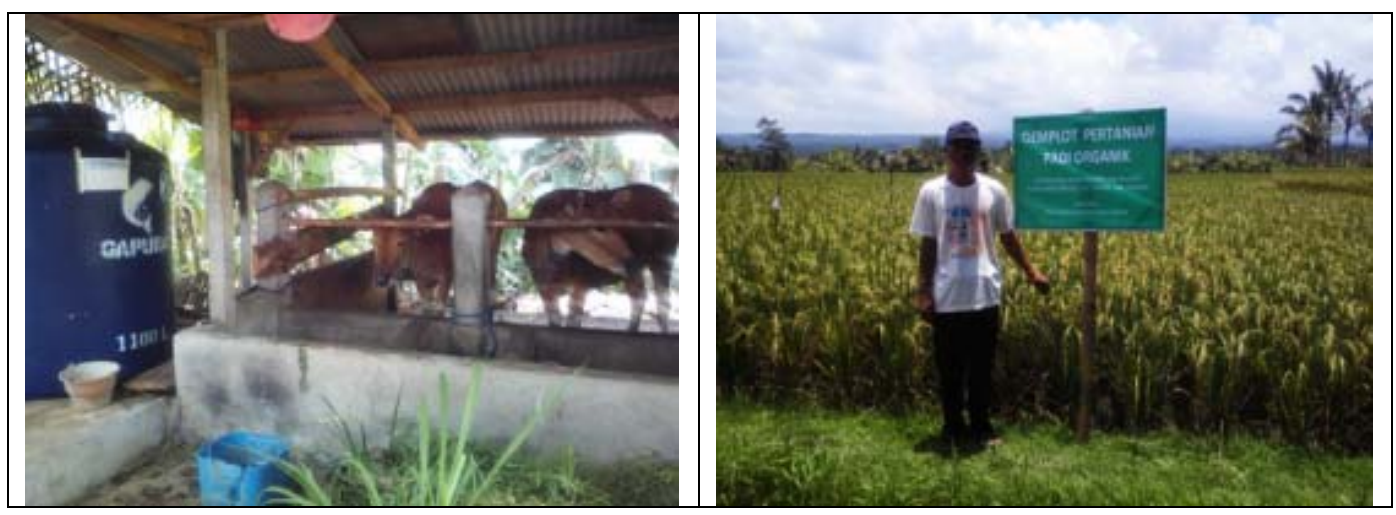

Gambar 1. Kegiatan IbW terkait Aplikasi POC dan Biopestisida pada Demplot padi organik

\section{KESIMPULAN DAN SARAN}

1. Pemberdayaan petani dengan desiminasi Ipteks melalui program IbW di desa Jegu dan Rejasa Kecamatan Penebel Kabupaten Tabanan berjalan sangat baik dengan sinergisme yang terjalin bagus antara Pemda, mitra, mayarakat sasaran dan tim pelaksana .

2. Kemampuan adopsi Ipteks dan inisiatif petani untuk memproduksi POC dan Biopestisida serta mengaplikasikan pada demplot dan lahan masing-masing cukup tinggi yaitu $74 \%$.

3. Prosentase partisipasi aktif masyarakat sasaran cukup tinggi yaitu $78,6 \%$

\section{UCAPAN TERIMAKASIH}

Ucapan terima kasih disampaikan kepada Direktorat Riset dan Pengabdian Masyarakat Kemenristek Dikti atas dana yang diberikan, Ketua Lembaga Penelitian dan Pengabdian kepada Masyarakat Universitas Udayana, Pemda Tabanan beserta SKPD terkait, mitra (UNDWI Denpasar) serta masyarakat sasaran (Subak Rejasa) atas kerjasamanya yang baik sehingga membantu kelancaran kegiatan ini.

\section{DAFTAR PUSTAKA}

Badan Perencanaan Pembangunan Kabupaten Tabanan, 2011. Rencana Pembangunan Jangka Menengah Kabupaten Tabanan.

Badan Statistik Provinsi Bali. 2011. Kabupaten Tabanan dalam Angka 2011.

Pemerintahan Desa Jegu. 2010. Profil Pembangunan Desa Jegu tahun 2010.

Pemerintahan Desa Rejasa. Data Potensi Desa dan Kelurahan Desa Rejasa tahun 2010. 